\title{
The effect of thoracic epidural analgesia on short-term outcome and mortality in geriatric patients undergoing open heart surgery
}

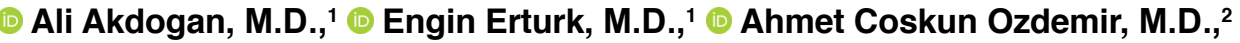 \\ (1) Dilek Kutanis, M.D., ${ }^{1}$ (1) Kibar Yasar Guven, M.D. ${ }^{2}$
}

${ }^{1}$ Department of Anesthesiology and Critical Care, Karadeniz Technical University Faculty of Medicine, Trabzon-Turkey

${ }^{2}$ Department of Cardiovascular Surgery, Karadeniz Technical University Faculty of Medicine, Trabzon-Turkey

\begin{abstract}
BACKGROUND: In open-heart surgeries, many organ functions, particularly the respiratory system, are affected by post-operative pain, and so is mortality. Following open-heart surgery, geriatric patients have a higher risk of organ dysfunction and mortality. We aimed to compare the short-term outcomes and mortality of thoracic epidural analgesia (TEA) and intravenous (IV) analgesia in geriatric patients undergoing open heart surgery.
\end{abstract}

METHODS: This study included patients over the age of 65 who had open-heart surgery between 2010 and 2020 . The patients were divided into two groups: Those who received TEA (Group E) and those who received IV paracetamol or tramadol or dexmedetomidine (Group I). The patients' post-operative sedation and analgesia requirements, mechanical ventilation (MV) duration, blood glucose levels, liver and kidney function tests, complications, intensive care and hospital stay lengths, and mortality rates were all compared.

RESULTS: The study included a total of 548 patients, with 408 in Group E and 140 in Group I. As a result of the comparisons between the groups, sedation requirement, analgesia requirement, MV duration, post-extubation facial mask oxygen requirement, noninvasive MV need, re-intubation requirement, and blood glucose level were found to be lower in Group E than in Group I. Moreover, periods spent in intensive care and lengths of hospital stay were found to be lower in Group E than Group I. There was no difference found between the two groups in terms of hospital mortality.

CONCLUSION: In elderly patients undergoing open-heart surgery, TEA reduced the length of time in intensive care and hospital stays by improving the respiratory status and blood glucose regulation by supplying analgesia and sedation.

Keywords: Cardiac surgery; elderly; post-operative; thoracic epidural analgesia.

\section{INTRODUCTION}

Post-operative pain has an impact on many organ systems, particularly the respiratory system, and thus morbidity and mortality in open-heart surgeries. Patients who are unable to breathe comfortably due to pain may experience various respiratory complications, including atelectasis, in the post-operative period. Furthermore, by inducing humoral and neuroendocrine changes, catecholamine discharge caused by surgical stress and pain can affect the functions of organs such as the liver and kidney. The elasticity and compliance in the lungs decrease with age, while functional residual capacity and residual volume increase. ${ }^{[I]}$ As a result, more pulmonary dysfunction and complications can be observed in elderly patients after heart surgery. Similarly, systolic and diastolic functions of the heart, as well as catecholamine response, decrease with age. [2] Renal blood flow and glomerular filtration decrease, and blood glucose regulation becomes difficult. ${ }^{[3]}$ As a result of all of these factors, geriatric patients could be more vulnerable to organ dysfunction and mortality after open-heart surgery. ${ }^{[4]}$

Cite this article as: Akdogan A, Erturk E, Ozdemir AC, Kutanis D, Guven KY. The effect of thoracic epidural analgesia on short-term outcome and mortality in geriatric patients undergoing open heart surgery. Ulus Travma Acil Cerrahi Derg 2022;28:382-389.

Address for correspondence: Ali Akdogan, M.D.

Karadeniz Teknik Üniversitesi Tıp Fakültesi, Anesteziyoloji ve Reanimasyon Anabilim Dalı, Trabzon, Turkey

Tel: +90 462 - 3775000 E-mail: draliakdogan@yahoo.com

Ulus Travma Acil Cerrahi Derg 2022;28(3):382-389 DOI: 10.14744/tjtes.2022.57995 Submitted: 27.10.202I Accepted: II.01.2022

Copyright 2022 Turkish Association of Trauma and Emergency Surgery 
Providing good post-operative analgesia can reduce both the surgical stress and the complications that may develop by suppressing the neuroendocrine response triggered by pain. When we examine the historical process, we can see that several modalities of analgesia have been used after openheart surgery. The use of systemic IV analgesics is one of the oldest and widely used methods. For this purpose, opioids, sedative analgesics such as clonidine and dexmedetomidine, as well as other analgesics like paracetamol, have also been used extensively. ${ }^{[5-7]}$ In heart surgery, regional anesthesia/analgesia techniques are widely used for post-operative analgesia. Epidural analgesia, which is used in a variety of surgical and non-surgical procedures, is often used in heart surgery in conjunction with general anesthesia due to its beneficial effects on the cardiovascular system. ${ }^{[8-13]}$ Thoracic epidural analgesia (TEA) is considered as the "gold standard" for the analgesia after thoracic region surgery. ${ }^{[14]}$ It has been also shown that TEA has also several additional advantages which are related (e.g., decrease in atelectasis, improvement of post-operative, and also posttraumatic respiratory functions) and not related (e.g., decrease in postoperative atrial fibrillation and provide less intraoperative bleeding) to analgesia. ${ }^{[15,16]}$ TEA has been reported to improve ventricular function, minimize the risk of myocardial infarction, and reduce the development of rhythm disorders. ${ }^{[17,18]}$ The positive effects of TEA on postoperative morbidity and mortality have been reported in several studies in the literature. However, the number of studies investigating the effects of TEA on the geriatric patient population undergoing open heart surgery is few. Because of the large number of patients involved, the study presented in this article has the potential to make significant contributions to the literature.

The aim of this retrospective study is to investigate the effects of TEA on post-operative respiratory parameters, blood glucose levels, liver and kidney functions, and mortality in geriatric patients who will have open-heart surgery. In accordance with this purpose, post-operative sedation and analgesia requirements, mechanical ventilation (MV) duration, blood glucose level, liver and kidney function tests, complications, lengths of intensive care and hospitality stay, and mortality rates of the patients who underwent TEA were compared with systemic IV tramadol or paracetamol or dexmedetomidine analgesia.

\section{MATERIALS AND METHODS}

Ethical approval for this study (Ethical Committee 2020/I82) was provided by the Ethical Committee Karadeniz Technical University, Faculty of Medicine, on July 6, 2020, and registered at http://www.clinicaltrials.gov (NCT04708080). Patients who had open-heart surgery in our hospital between January I, 2010, and December 31, 2020, were included in this study, which was intended as a retrospective study. The study was carried out by scanning patient files from the hospital archive. To achieve objective results, data records were carried out by individuals who were not participants in the study.
Standard analgesia protocols are used for post-operative analgesia in all patients who have had open-heart surgery for a long time in the hospital where this study was performed. As an analgesic method, primarily TEA is used, and patients' analgesia is provided with TEA both in the intraoperative period and the post-operative period. However, patients are given fentanyl infusion during the intraoperative period if there are any contraindications for TEA, TEA procedure failure, or a shortage of necessary equipment or drugs for TEA. In the post-operative period, one of the drugs tramadol, paracetamol, or dexmedetomidine is provided to these patients receiving IV analgesia.

Patients in the operating room receive sedoanalgesia with intravenous (IV) midazolam and fentanyl after electrocardiography, peripheral oxygen saturation, and non-invasive blood pressure monitoring are performed as standard. Then, using a Tuohy needle, an epidural catheter is inserted through the T5-T6 interval by experienced clinician. $15 \mu \mathrm{g}$ adrenaline in 3-5 $\mathrm{ml}$ of $0.9 \% \mathrm{NaCl}$ was administered to exclude IV insertion. After confirming the epidural catheter's position, a bolus of $25 \mathrm{mg} / 10 \mathrm{ml}$ bupivacaine is administered, followed by a 3-4 $\mathrm{ml} /$ hour bupivacaine infusion from a $3 \mathrm{mg} / \mathrm{ml}$ solution, which is continued until the post-operative $48^{\text {th }} \mathrm{h}$. The epidural catheter is removed at the end of the $2^{\text {nd }}$ post-operative day, depending on the type of anticoagulant used on the patient, in compliance with standard protocols. Intraoperative I $\mu \mathrm{g} /$ $\mathrm{kg} / \mathrm{h}$ fentanyl infusion is administered as an analgesic protocol to patients who do not receive TEA. For post-operative analgesia, on the other hand, one of the following three options is administered intravenously: $50 \mathrm{mg}$ tramadol 4 times per day or I g paracetamol 3 times per day or $0.1-1 \mu g / k g / h$ dexmedetomidine infusion.

For anesthesia induction, patients are given $2-4 \mathrm{~g} / \mathrm{kg}$ fentanyl, 3-6 $\mathrm{mg} / \mathrm{kg}$ thiopental, and I $\mathrm{mg} / \mathrm{kg}$ rocuronium. I-3\% sevoflurane in a $50 \%$ oxygen-air mixture is used to maintain anesthesia. Invasive blood pressure and nasopharyngeal temperature monitoring are undertaken after orotracheal intubation. The monitoring of anesthesia depth is provided by the bispectral index. After the procedure, all patients are transferred to the intensive care unit (ICU) as intubated, where MV is maintained. Patients in intensive care are administered a $\mathrm{I}-2 \mathrm{mg}$ infusion of midazolam for the first $2 \mathrm{~h}$. The patients whose Richmond Agitation-Sedation Scale score were between + I and +4 are given additional sedative drugs (midazolam and haloperidol). Patients with a numeric rating scale score of more than 4 are given additional analgesic medication (50 $\mathrm{mg}$ of tramadol or I $\mathrm{g}$ of paracetamol, or $50 \mathrm{mcg}$ of fentanyl). Patients who have a $\mathrm{PaO}_{2}$ value of $70 \mathrm{mmHg}$ in the blood gas and $\mathrm{a} \mathrm{SaO}_{2}$ of more than $90 \%$ when breathing in pressure-supported spontaneous mode with $0.50 \mathrm{FiO}_{2}$ and 5 $\mathrm{cmH}_{2} \mathrm{O}$ PEEP are extubated, and additional oxygen with face mask and other needs are met according to protocol. Highflow oxygen support is primarily provided with a face mask for spontaneous breathing, as per the protocols for patients 
whose breathing deteriorates after extubation. Patients that have a peripheral oxygen saturation of $<90 \%$ despite oxygen support are given non-invasive MV (NIMV). Patients who do not regain their oxygenation after receiving NIMV are reintubated and mechanically ventilated.

In this study, groups were formed by dividing the patients into two groups as those who received TEA (Group E) and those who received IV analgesia (Group I) in line with the above-mentioned information. Intensive care follow-up tables and hospital computer records were examined for the study parameters. Patients under the age of 65, those who operated after cardiac arrest, very urgent operations, patients whose data could not be obtained, and those to whom more than one analgesia method and drugs were given were not included in the study.

Patients' demographic data, ejection fraction (EF), ASA (American Society of Anesthesiologists), and EuroSCORE risk scores, pulmonary function (PF) tests, comorbid diseases, and surgery types were all recorded as pre-operative followup parameters. When it comes to intraoperative follow-up parameters, patients' hemodynamic data, the length of cardiopulmonary bypass and aortic cross-clamp, amount of fluid and blood products provided to patients, and urine output data were recorded. As post-operative follow-up parameters, on the other hand, MV duration, sedative and analgesic drug requirements were recorded according to sedation and pain scores. Patients' additional oxygen needs after extubation during their stay in intensive care, NIMV needs, reintubation requirements, respiratory problems like pneumonia, blood glucose, liver and kidney function tests, and renal support system requirements such as hemodialysis were all recorded. The amount of fluid and blood products taken by the patients, length of stay in intensive care and hospitalization, and mortality rates were also recorded in addition to their hemodynamic data and inotropic drug requirement.

The data were analyzed using IBM SPSS V23. Mann-Whitney $U$ test was used to compare the quantitative data by groups. The Chi-square test was used to analyze the categorical data. The quantitative data were presented as mean \pm standard deviation, while categorical data were presented as frequency (percentage). The level of significance was accepted as $p<0.05$.

\section{RESULTS}

In this study, it was found that a total of 1574 patients had undergone open-heart surgery between 2010 and 2020. A total of 1026 patients were not included in the study because 847 patients were younger than 65 years, 106 patients underwent very emergency surgery, 28 patients did not meet the inclusion criteria, and 45 patients' data were not available Consequently, 408 patients were included in the study as the epidural group (Group E) and I 40 patients as the IV analgesia group (Group I) (Fig. I).

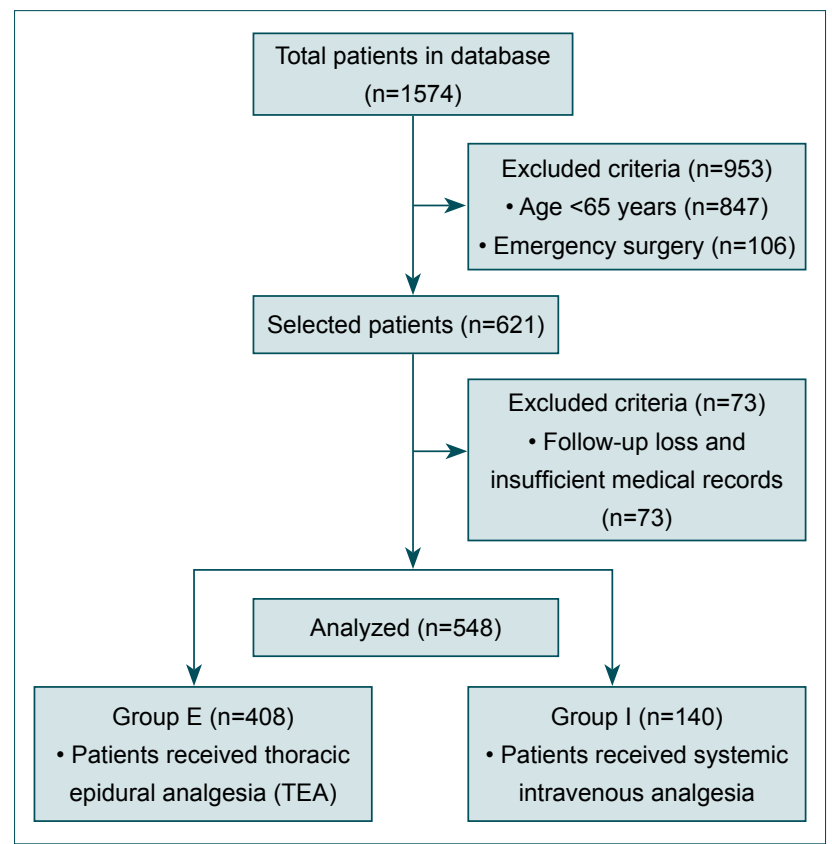

Figure 1. Flow diagram for patient selection.

The preoperatively recorded data revealed no significant differences in terms of age, gender, BMI, EF, ASA, and EuroSCORE risk scores (Table I). There was no significant difference between the groups in terms of comorbidity and types of surgery. However, in the PF test examinations, the FEVI/FVC (Forced Expiratory Volume in one second/Forced Vital Capacity) mean value of Group E (77.4 I 2.9) was found to be significantly lower than the mean value of Group I $(81.5 \pm 10.9)$. Furthermore, the percentage of patients with FEVI/FVC ratio $<70$ in Group E (16.4\%) was found to be higher than Group I (I.8\%) $(p<0.05)$, (Table I).

The cardiopulmonary bypass and aortic cross-clamp duration of the patients were not significantly different. However, a significant difference was found between postoperative MV times, time spent in the ICU, and hospital stay (Table 2). The post-operative MV time in Group E (10.6 $12.6 \mathrm{~h})$ was found to be shorter than that of Group I (19.2 \pm I7.4 h). Concordantly, the time spent in the ICU $(2.5 \pm 2.4$ days $)$ and the duration of hospitalization ( $7.3 \pm 3.8$ days) in Group $E$ has been found to be shorter than the time spent in the ICU $(4.1 \pm 2.5$ days) and the duration of hospitalization ( $10.5 \pm 6.6$ days) in Group I $(p<0.05$ and $p<0.0$ I, respectively).

Significant differences were found between patients' additional sedation and analgesic requirements. The percentage of patients in Group E who needed additional sedation (5I patients, $25 \%$ ) was found to be lower than the percentage of patients in Group I (32 patients, 47.7\%) ( $p<0.01)$. Similarly, the percentage of patients in Group $E$ who needed additional analgesics (I 32 patients, $32.3 \%$ ) was statistically significantly lower than the percentage of patients in Group I (78 patients, $55.4 \%)(p<0.01)$, (Fig. 2). 
Table I. Patient characteristics and surgery performed in the study groups

\begin{tabular}{|c|c|c|c|}
\hline & Group I $(n=\mid 40)$ & Group E $(n=408)$ & $\mathbf{p}$ \\
\hline Age (years) & $72.1 \pm 6.1$ & $71.7 \pm 4.1$ & 0.227 \\
\hline Gender (M/F) & $106 / 34$ & $120 / 288$ & 0.445 \\
\hline BMI & $28 . I \pm 4.4$ & $28.2 \pm 4.5$ & 0.865 \\
\hline ASA (II/III/IV/V) & $18 / 78 / 38 / 6$ & $42 / 270 / 96 / 0$ & 0.252 \\
\hline EF (\%) & $52.4 \pm 10.7$ & $51.3 \pm 11.8$ & 0.310 \\
\hline Euro Score & $4.4 \pm 2.0$ & $4.3 \pm 1.9$ & 0.624 \\
\hline \multicolumn{4}{|l|}{ Comorbidity, n (\%) } \\
\hline Hypertension & II 8 (84.2) & $316(77.4)$ & 0.14 \\
\hline Smoking & $28(20)$ & $52(12.7)$ & 0.10 \\
\hline Diabetus mellitus & $40(28.5)$ & $108(22.5)$ & 0.42 \\
\hline Hypercholesterolemia & $18(12.8)$ & $54(13.2)$ & 0.55 \\
\hline Previous stroke & $8(5.7)$ & $14(3.4)$ & 0.30 \\
\hline Arrhythmia & $16(11.4)$ & $60(14.7)$ & 0.32 \\
\hline Kidney function disorder & $14(10)$ & $42(10.2)$ & 0.51 \\
\hline Chronic obstructive pulmonary disease & $24(17.1)$ & $70(17)$ & 0.57 \\
\hline FEV,/FVC (\%) & $81.5 \pm 10.9$ & $77.4 \pm 12.9$ & $0.015^{*}$ \\
\hline Patient with FEV,/FVC < 70\% n (\%) & $10(1.8)$ & $90(16.4)$ & $0.025^{* *}$ \\
\hline \multicolumn{4}{|l|}{ Type of cardiac procedure, n (\%) } \\
\hline Coronary bypass only & $112(20.5)$ & $316(57.6)$ & \\
\hline Valvular disease only & $8(1.4)$ & $50(9.1)$ & \\
\hline Aort aneurysm & $8(1.4)$ & $6(1)$ & \\
\hline Coronary bypass \& valvular disease & $8(1.4)$ & $30(5.4)$ & \\
\hline Valvular + Aort aneurysm & $0(0)$ & $2(0.3)$ & \\
\hline Coronary bypass + Aort aneurysm & $2(0.3)$ & $0(0)$ & \\
\hline Coronary bypass + Valvular + Aort aneurysm & $2(0.3)$ & $2(0.3)$ & \\
\hline
\end{tabular}

"P $<0.05 \mathrm{FEVI} / \mathrm{FVC}$ rate in Group $\mathrm{E}$ is lower than Group I. " $\mathrm{P}<0.05$ Patients'rate with $\mathrm{FEV} / \mathrm{FVC}$ rate $<70 \%$ in Group $\mathrm{E}$ is higher than Group I. CABG: Coronary artery bypass grafting; BMI: Body mass index; ASA: American Society of Anesthesiologists; EF: Ejection fraction.

Table 2. Patients' preoperative and posotoperative laboratory values (Mean \pm SD)

\begin{tabular}{lccc}
\hline & Group I & Group E & p \\
\hline Preoperative aspartate aminotransferase (IU/L) & $30.46 \pm 23.87$ & $32.2 \pm 47.1$ & 0.55 \\
Postoperative aspartate aminotransferase (IU/L) & $79.62 \pm 77.92$ & $91.2 \pm 78.5$ & 0.44 \\
Preoperative alanine aminotransferase (IU/L) & $21.39 \pm 15.88$ & $23.96 \pm 50.44$ & 0.36 \\
Postoperative alanine aminotransferase (IU/L) & $35.07 \pm 52.1$ & $45.5 \pm 57.1$ & 0.35 \\
Preoperative creatinine (mg/dL) & $1.08 \pm 0.65$ & $1.19 \pm 1.13$ & 0.33 \\
Postoperative creatinine (mg/dL) & $1.07 \pm 0.71$ & $1.12 \pm 0.77$ & 0.26 \\
Preoperative glucose (mg/dl) & $120.7 \pm 49.6$ & $127.4 \pm 56.9$ & 0.22 \\
Postoperative glucose (mg/dl) & $181.5 \pm 49.0$ & $152.1 \pm 54.7$ & $0.03^{*}$ \\
\hline
\end{tabular}

${ }^{*} \mathrm{P}<0.05$ postoperative glucose value in Group $\mathrm{E}$ is lower than Group I. SD: Standard deviation.

Post-operative blood glucose levels, liver, and kidney function tests all revealed some differences (Table 3). Blood glucose level in Group E $(152.1 \pm 54.7 \mathrm{mg} / \mathrm{d})$ was found to be lower than that of Group I $(181.5 \pm 49.0 \mathrm{mg} / \mathrm{dl})$. While Group E had slightly higher creatinine $(1.12 \pm 0.77 \mathrm{mg} / \mathrm{dL})$, ALT $(45.5 \pm 57.1$ $\mathrm{IU} / \mathrm{L})$, and AST $(91.2 \pm 78.5 \mathrm{IU} / \mathrm{L})$ values than Group I crea- 
Table 3. Data on surgical and postoperative periods (Mean \pm SD)

\begin{tabular}{|c|c|c|c|}
\hline & Group I $(n=\mid 40)$ & Group E $(n=408)$ & $\mathbf{p}$ \\
\hline Pump time (min) & $|29.4 \pm 4| .4$ & $139.3 \pm 52.6$ & 0.180 \\
\hline ACC time (min) & $81.7 \pm 35.5$ & $86.9 \pm 41.1$ & 0.316 \\
\hline MV times (hours) & $19.2 \pm 17.4$ & $10.6 \pm 12.6$ & $0.021^{*}$ \\
\hline ICU stay (day) & $4.1 \pm 2.5$ & $2.5 \pm 2.4$ & $0.035^{*}$ \\
\hline Hospital stay (day) & $10.5 \pm 6.6$ & $7.3 \pm 3.8$ & $0.008^{* *}$ \\
\hline Hospital mortality & $6(1 \%)$ & 18 (3.2\%) & 0.632 \\
\hline
\end{tabular}

tinine $(\mathrm{I} .07 \pm 0.7 \mathrm{I} \mathrm{mg} / \mathrm{dl})$, ALT $(35.07 \pm 52.1 \mathrm{IU} / \mathrm{L})$, and AST $(79.62 \pm 77.92 \mathrm{IU} / \mathrm{L})$ values, this difference did not reach statistically significant levels $(p>0.05)$.

When the post-operative complications of the two groups were compared, it was found that there were significant differences, particularly in terms of pulmonary functions. The proportions of patients who need additional oxygen support with a face mask because their breathing worsened after being extubated ( 113 patients, $27.7 \%$ ), who need NIMV (3I pa-

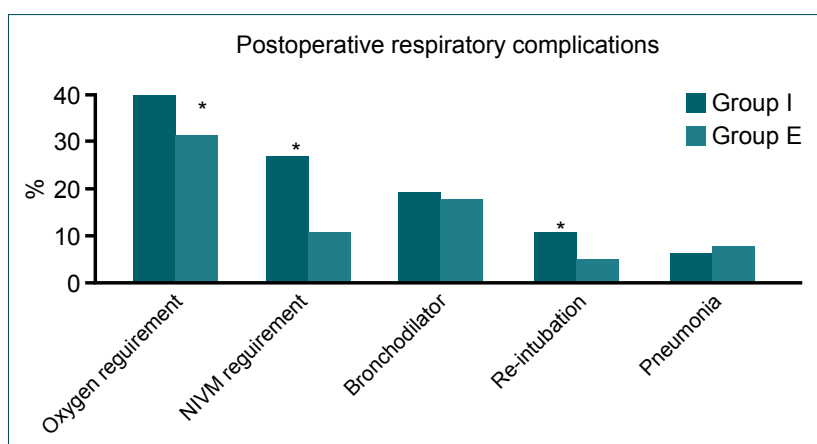

Figure 2. Postoperative respiratory complications. " $P<0.05$, NIMV requirement, oxygen requirement and re-intubation in Group $E$ is lower than Group I. NIMV: Noninvasive mechanical ventilation.

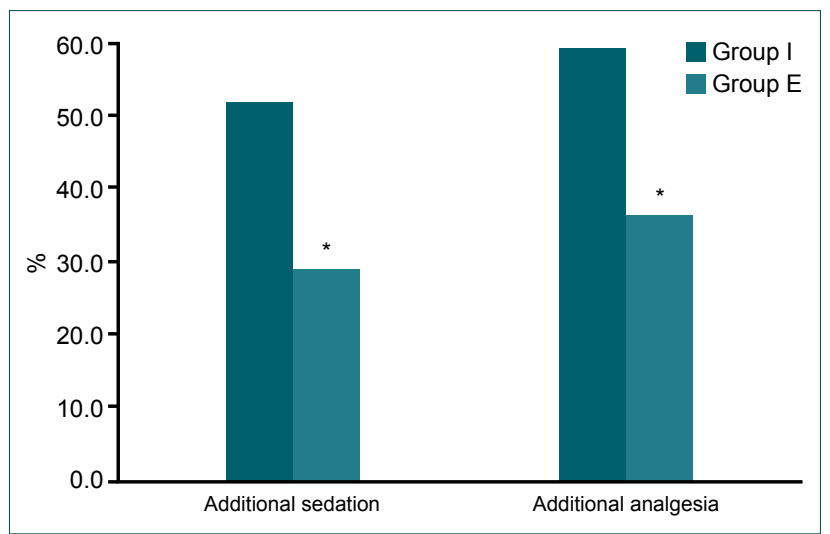

Figure 3. Patients' rate of additional sedative and analgesic drug requirement. " $\mathrm{P}<0.01$ additional sedative and analgesic requirement in Group E are lower than Group I. tients, 7.6\%), and who underwent reintubation (3 patients, I.5\%) were found to be lower in Group E than in Group I (5I patients, $36.2 \%$; 16 patients, $23.2 \%$; and 5 patients, $7.1 \%$, respectively), ( $p<0.05)$, (Fig. 3).

There was no significant difference found between the groups in terms of infection development (e.g., pneumonia), hemodynamic data, development of the need for inotropic/vasopressor drugs, and fluid and blood products supplied. Both groups had comparable in-hospital mortality rates $(p>0.05)$.

\section{DISCUSSION}

This study demonstrated that TEA offers better analgesia and sedation in open-heart surgery than systemic IV analgesics, enabling patients to be extubated sooner and reducing respiratory complications. By suppressing the post-operative stress response, TEA also helped to regulate blood glucose levels. TEA led to a decrease in the duration of stay in both the ICU and the hospital as a consequence of all of these positive outcomes. This study has the highest number of geriatric patients for cardiac surgery with TEA. Although several studies were conducted to investigate the effects of TEA on the geriatric patients in the literature, ${ }^{[19]}$ no study has reached to our patients' number. Therefore, the results of this study have great importance.

After open heart surgery, deep breathing induces tension in the sternotomy area, resulting in intense pain. The patient, whose pain worsens as he breathes, begins to breathe more superficially to restrain the amount of pain he experiences. Atelectasis, infection, and other respiratory complications may arise as a consequence of this problem, resulting in worse outcomes regarding morbidity and mortality. In a retrospective analysis of 5798 patients who underwent cardiac surgery, Castillo et al. ${ }^{[4]}$ reported that being over the age of 70 increases the risk of respiratory failure. TEA offers great post-operative analgesia, enabling patients to be extubated sooner and the duration of MV to be reduced. Moreover, it reduces the complications that may be caused by surgical pain and contributes positively to respiratory functions. In a recent study involving 90 patients who underwent coronary 
artery bypass graft surgery, Meena and Ranawat ${ }^{[20]}$ found that TEA administration offered better analgesia than IV fentanyl administration and that patients were extubated sooner. They also claimed that TEA improved patients' post-operative pulmonary functions by improving arterial blood gases value and peak expiratory flow rate. In the literature, there are several meta-analyses stating that TEA application has positive effects especially on respiratory functions and decreases respiratory complications. ${ }^{[21-23]}$ In a meta-analysis that included only randomized controlled trials, Zhang et al. ${ }^{[23]}$ reported that patients who underwent TEA were extubated sooner and had fewer respiratory complications. As a result of their examination on 69 randomized controlled trials involving 4860 patients in a meta-analysis conducted in 2019, Guay and Kopp found that TEA administration offered improved analgesia up to the $72^{\text {nd }} \mathrm{h}$ postoperatively compared to systemic IV analgesia, reduced MV duration by allowing sooner extubation, and reduced the rate of respiratory complications. ${ }^{[17]}$ In our study, patients who received TEA required less additional analgesic, were extubated sooner, and spent less time on MV than those who received IV analgesia. After extubation, the positive effects of TEA on respiratory functions persisted, and the rate of mask oxygen and NIMV requirement and post-operative reintubation were shown to be lower in the TEA group than in the IV analgesia group.

In the literature, there are many studies demonstrating the positive effects of TEA administration on respiratory functions in the post-operative period using PF test parameters. To determine the effects of TEA on respiratory functions of patients over 65 years of age who undergone open-heart surgery, El-Morsy et al. ${ }^{[2]}$ administered only intravenously fentanyl to one group and TEA to the other. They found that aside from better analgesia and sooner extubation, patients who underwent TEA in the post-operative phase also had higher FVC and FEVI values in PF tests. While all patients receive pre-operative PF tests, routine PF tests are not administered in the post-operative phase at our hospital. Hence, we are unable to speculate on the effects of TEA on our patients' post-operative PF tests. However, having a weaker respiratory condition according to the pre-operative FEVI/ FVC rates, the patients in the TEA community exhibited a better clinical course in the post-operative phase the fact that the TEA group needed less additional oxygen, NIMV, and reintubation after extubation than the IV analgesia group can be considered evidence of TEA's positive effects on respiratory functions.

Surgical stress and pain can increase sympathetic activity and cause neuroendocrine changes in patients, leading to increased morbidity and mortality. Catecholamine release suppresses insulin secretion and increases glycogenolysis, causing blood glucose to rise. In addition to its cardiac and respiratory benefits, it has been reported that TEA application reduces complications by suppressing the catecholamine and cortisol response associated with surgery. ${ }^{[25]}$ Zawar et al. ${ }^{[2]}$ reported that TEA administration suppressed the stress response and shortened the hospital stay in elderly patients undergoing cardiac surgery. In another study, it was reported that hyperglycemia has a significant impact on mortality, and insulin infusion for blood glucose regulation lowers perioperative complications and mortality. ${ }^{[2]}$ In our study, patients who received TEA needed less post-operative sedation than those who received IV analgesia, and their blood glucose levels were lower. We believe that better control of stress response and catecholamine discharge with epidural analgesia is the reason for the favorable situation for TEA in terms of blood glucose among groups with comparable DM and other comorbidities.

TEA administration may have some effects on hemodynamic functions, as well as vital organ functions such as the liver and kidney. Guay and Kopp reported that TEA raised the risk of hypotension, but there was no need for inotropic or vasopressor drugs, in a meta-analysis of 17 randomized controlled trials involving 870 patients. ${ }^{[1]}$ In our study, no differences in hemodynamic parameters or the use of inotropic/vasopressor drugs were observed between the groups. However, being within usual limits, blood pressure levels in the TEA group were lower than in the systemic analgesia group, but not statistically significant. By influencing organ perfusion, a drop in blood pressure has the potential to impair liver and kidney functions. In our study, creatinine, ALT, and AST values in epidural group were slightly higher than in the systemic IV analgesia group, but the difference was not statistically significant. This situation reveals the fact that TEA administration should be closely monitored in terms of organ perfusion.

TEA has the potential to improve patient clinical outcomes and reduce the duration of stay in the ICU and hospital with its beneficial effects on respiratory processes and stress response. ${ }^{[10,27]}$ In a study of patients who undergone heart surgery, Bracco et al. ${ }^{[28]}$ reported that using TEA reduced the duration of stay both in the intensive care and hospital by reducing post-operative complications, and provided a reduction in the costs of patients. We were unable to calculate the cost of our patients. However, the fact that TEA-applied patients spent less time both in the ICU and the hospital can be considered an advantage.

In this study, both groups had comparable mortality rates. Apart from meta-analyses claiming that TEA decreases mortality, there are also studies claiming that it has no impact in the literature. ${ }^{[22,23,29]}$ The number of studies claiming that less invasive procedures such as erector spinae plane block and pectoral nerve block can be used in cardiac surgery for analgesic purposes is increasing by the day, based on the thesis that TEA application has no beneficial impact on mortality and has significant side effects such as epidural hematoma. ${ }^{[30,31]}$ These practices are promising, but they will need to be implemented more widely and more studies conducted to truly show their efficacy. In our TEA applications, which we conducted according to guideline of the neuraxial block in the patient receiving 
antithrombotic or thrombolytic drugs, ${ }^{[32]}$ no clinically significant hemorrhagic complications were observed.

This study, in which we emphasized the advantages of TEA in open-heart surgery, has some limitations. First and foremost, this is a retrospective study that spans a long period of time, about 10 years. Various anesthesia and surgery teams were involved in the surgical processes of the patients during the course of this long period. In the processes of analgesia applications, MV and extubation, and discharge from intensive care and the hospital, it has been difficult to reach a strict standard with objective criteria. Other limitation of the study is that the groups did not include equal numbers of patients. Another limitation is that some patients were excluded from the study if all records for the study period could not be accessed and if it was found that all analgesia methods were used simultaneously.

\section{Conclusion}

It was seen in this study that TEA offers better analgesia and sedation in open-heart surgery, improves respiratory status by reducing the duration of $\mathrm{MV}$ and respiratory complications, and makes a positive contribution to the regulation of blood glucose levels. TEA also reduced the duration of stay in both the ICU and hospital. We believe that TEA application contributes significantly to clinical outcomes in open-heart surgery, on the condition of being conducted by experienced anesthesiologists and vital organ functions are closely monitored.

\section{Informed Consent}

The study complies with the current ethical considerations. None of the authors has any conflict of interest, financial or otherwise. All participants provided informed consent in the format required by the relevant authorities.

Ethics Committee Approval: This study was approved by the Karadeniz Technical University Scientific Research Ethics Committee (Date: 09.07.2020, Decision No: 424).

Peer-review: Internally peer-reviewed.

Authorship Contributions: Concept: K.Y.G., D.K., A.A., E.E., A.C.O.; Design: A.A., E.E.; Supervision: A.A., E.E., A.C.O., D.K.; Resource: A.A., E.E., K.Y.G., D.K.; Materials: A.A., A.C.O., K.Y.G., D.K.; Data: A.A., E.E., A.C.O., D.K., K.Y.G.; Analysis: A.A., E.E., D.K.; Literature search: A.A., E.E., D.K., A.C.O.; Writing: A.A., E.E., D.K.; Critical revision: A.A., E.E., D.K.

\section{Conflict of Interest: None declared.}

Financial Disclosure: The authors declared that this study has received no financial support.

\section{REFERENCES}

1. Buchman AS, Boyle PA, Wilson RS, Gu L, Bienias JL, Bennett DA. Pulmonary function, muscle strength and mortality in old age. Mech Ageing
Dev 2008;129:625-31. [CrossRef]

2. Zawar BP, Mehta Y, Juneja R, Arora D, Raizada A, Trehan N. Nonanalgesic benefits of combined thoracic epidural analgesia with general anesthesia in high risk elderly off pump coronary artery bypass patients. Ann Card Anesth 2015;18:385-91. [CrossRef]

3. Coresh J, Selvin E, Stevens LA, Manzi J, Kusek JW, Eggers P, et al. Prevalence of chronic kidney disease in the United States. JAMA 2007;298:2038-47. [CrossRef]

4. Castillo JG, Silvay G, Chikwe J. Cardiac anesthesia and surgery in geriatric patients: Epidemiology, current surgical outcomes, and future directions. HSR Proc Intensive Care Cardiovasc Anesth 2009;1:6-19.

5. Shankar P, Mueller A, Packiasabapathy S, Gasangwa D, Patxot M, O'Gara $\mathrm{B}$, et al. Dexmedetomidine and intravenous acetaminophen for the prevention of postoperative delirium following cardiac surgery (DEXACET trial): Protocol for a prospective randomized controlled trial. Trials 2018;19:326. [CrossRef]

6. Wang G, Niu J, Li Z, Lv H, Cai H. The efficacy and safety of dexmedetomidine in cardiac surgery patients: A systematic review and meta-analysis. PLoS One 2018;13:e0202620. [CrossRef]

7. de Hoogd S, Ahlers SJ, van Dongen EP, Tibboel D, Dahan A, Knibbe CA. Remifentanil versus fentanyl during cardiac surgery on the incidence of chronic thoracic pain (REFLECT): Study protocol for a randomized controlled trial. Trials 2014;15:466. [CrossRef]

8. Erturk E, Kaya FA, Kutanis D, Besir A, Akdogan A, Geze S, et al. The effectiveness of preemptive thoracic epidural analgesia in thoracic surgery. Biomed Res Int 2014;2014:673682. [CrossRef]

9. Hutchins JL, Grandelis AJ, Kaizer AM, Jensen EH. Thoracic paravertebral block versus thoracic epidural analgesia for post-operative pain control in open pancreatic surgery: A randomized controlled trial. J Clin Anesth 2018;48:41-5. [CrossRef]

10. Monaco F, Pieri M, Barucco G, Karpatri V, Redaelli MB, de Luca M, et al. Epidural analgesia in open thoraco-abdominal aortic aneurysm repair. Eur J Vasc Endovasc Surg 2019;57:360-7. [CrossRef]

11. Kawaguchi R, Yamauchi M, Sugino S, Yamakage M. Ultrasound-aided ipsilateral-dominant epidural block for total hip arthroplasty: A randomised controlled single-blind study. Eur J Anesthesiol 2011;28:13740. [CrossRef]

12. Tveit TO, Seiler S, Halvorsen A, Rosland JH. Labour analgesia: A randomised, controlled trial comparing intravenous remifentanil and epidural analgesia with ropivacaine and fentanyl. Eur J Anesthesiol 2012;29:129-36. [CrossRef]

13. Erturk E, Bostan H, Eroglu A. Epidural analgesia and vaginal delivery in a patient with aortic stenosis and insufficiency. Med Princ Pract 2011;20:574-6. [CrossRef]

14. Senturk M. Acute and chronic pain after thoracotomies. Curr Opin Anaesthesiol 2005;18:1-4. [CrossRef]

15. Ulke ZS, Sentürk M. Non-analgesic effects of thoracic epidural anesthesia. Agri 2007;2:6-12.

16. Açan AE, Kilınç CY, Gültaç E, Altıparmak B, Uysal Aİ, Aydoğan NH. Effects of different anesthesia techniques on intraoperative blood loss in acetabular fractures undergoing the modified stoppa approach.Ulus Travma Acil Cerrahi Derg 2020;3:445-52. [CrossRef]

17. Guay J, Kopp S. Epidural analgesia for adults undergoing cardiac surgery with or without cardiopulmonary bypass. Cochrane Database Syst Rev 2019;3:CD006715. [CrossRef]

18. Elgebaly AS, Fathy SM, Elbarbary Y, Sallam AA. High thoracic epidural decreases perioperative myocardial ischemia and improves left ventricle function in aortic valve replacement alone or in addition to CABG surgery even with increased left ventricle mass index. Ann Card Anesth 
2020;23:154-60. [CrossRef]

19. Caputo M, Alwair H, Rogers CA, Pike K, Cohen A, Monk C, et al. Thoracic epidural anesthesia improves early outcomes in patients undergoing off-pump coronary artery bypass surgery: A prospective, randomized, controlled trial. Anesthesiology 2011;114:380-90. [CrossRef]

20. Meena R, Ranawat P. A prospective randomized study of the post-operative outcomes of thoracic epidural analgesia in patients undergoing coronary artery bypass graft surgery. Indian J Clin Anesth 2020;7:71-6.

21. Svircevic V, Passier MM, Nierich AP, van Dijk D, Kalkman CJ, van der Heijden GJ. Epidural analgesia for cardiac surgery. Cochrane Database Syst Rev 2013;6:CD006715. [CrossRef]

22. Landoni G, Isella F, Greco $M$, Zangrillo $A$, Royse CF. Benefits and risks of epidural analgesia in cardiac surgery. Br J Anesth 2015;115:25-32.

23. Zhang S, Wu X, Guo H, Ma L. Thoracic epidural anesthesia improves outcomes in patients undergoing cardiac surgery: Meta-analysis of randomized controlled trials. Eur J Med Res 2015;20:25. [CrossRef]

24. El-Morsy GZ, El-Deeb A. The outcome of thoracic epidural anesthesia in elderly patients undergoing coronary artery bypass graft surgery. Saudi J Anaesth 2012;6:16-21. [CrossRef]

25. Mehta Y, Arora D, Vats M. Epidural analgesia in high risk cardiac surgical patients. HSR Proc Intensive Care Cardiovasc Anesth 2012;4:11-4.

26. Furnary AP, Gao G, Grunkemeier GL, Wu Y, Zerr KJ, Bookin SO, et al. Continuous insulin infusion reduces mortality in patients with diabetes undergoing coronary artery bypass grafting. J Thorac Cardiovasc Surg 2003;125:1007-21. [CrossRef]
27. Sharma M, Mehta Y, Sawhney R, Vats M, Trehan N. Thoracic epidural analgesia in obese patients with body mass index of more than 30 $\mathrm{kg} / \mathrm{m} 2$ for off pump coronary artery bypass surgery. Ann Card Anesth 2010;13:28-33. [CrossRef]

28. Bracco D, Noiseux N, Dubois MJ, Prieto I, Basile F, Olivier JF, et al. Epidural anesthesia improves outcome and resource use in cardiac surgery: A single-center study of a 1293-patient cohort. Heart Surg Forum 2007;10:449-58. [CrossRef]

29. Svircevic V, van Dijk D, Nierich AP, Passier MP, Kalkman CJ, van der Heijden GJ, et al. Meta-analysis of thoracic epidural anesthesia versus general anesthesia for cardiac surgery. Anesthesiology 2011;114:27182. [CrossRef]

30. Nagaraja PS, Ragavendran S, Singh NG, Asai O, Bhavya G, Manjunath $\mathrm{N}$, et al. Comparison of continuous thoracic epidural analgesia with bilateral erector spinae plane block for perioperative pain management in cardiac surgery. Ann Card Anesth 2018;21:323-7. [CrossRef]

31. Kumar KN, Kalyane RN, Singh NG, Nagaraja PS, Krishna M, Babu $\mathrm{B}$, et al. Efficacy of bilateral pectoralis nerve block for ultrafast tracking and postoperative pain management in cardiac surgery. Ann Card Anesth 2018;21:333-8. [CrossRef]

32. Horlocker TT, Vandermeuelen E, Kopp SL, Gogarten W, Leffert LR, Benzon HT. Regional anesthesia in the patient receiving antithrombotic or thrombolytic therapy: American society of regional anesthesia and pain medicine evidence-based guidelines (Fourth Edition). Reg Anesth Pain Med 2018;43:263-309. [CrossRef]

\section{ORİJINAL ÇALIŞMA - ÖZ}

\section{Açık kalp cerrahisi olan geriatrik hastalarda torasik epidural analjezinin kısa dönem sonuç ve mortalite üzerine etkisi}

\section{Dr. Ali Akdogan, ${ }^{1}$ Dr. Engin Erturk, ${ }^{1}$ Dr. Ahmet Coskun Ozdemir, ${ }^{2}$ Dr. Dilek Kutanis, ${ }^{1}$ Dr. Kibar Yasar Guven ${ }^{2}$}

${ }^{1}$ Karadeniz Teknik Üniversitesi Tıp Fakültesi, Anesteziyoloji ve Reanimasyon Anabilim Dalı, Trabzon

${ }^{2}$ Karadeniz Teknik Üniversitesi Tıp Fakültesi, Kalp Damar Cerrahisi Anabilim Dalı, Trabzon

AMAÇ: Ameliyat sonrası ağıı, açık kalp ameliyatlarında solunum sistemi başta olmak üzere birçok organ fonksiyonlarını ve mortaliteyi etkiler. Geriatrik hastalar açık kalp cerrahisi sonrası daha fazla organ disfonksiyonu ve mortalite riski altındadırlar. Açık kalp cerrahisi geçiren geriatrik hastalarda torasik epidural analjezi (TEA) ve intravenöz analjezinin kısa dönem sonuçlarını ve mortalitesini karşılaştırmayı amaçladık.

GEREÇ VE YÖNTEM: Bu çalışmaya 20 I 0-2020 yılları arasında açık kalp cerrahisi geçiren 65 yaş üstü hastalar alındı. Hastalar torasik epidural analjezi uygulananlar (Grup E) ve intravenöz parasetamol veya tramadol veya deksmedetomidin uygulananlar (Grup I) olmak üzere iki gruba ayrıldı. Hastaların ameliyat sonrası sedasyon ve analjezi gereksinimleri, mekanik ventilasyon süreleri, kan glukoz düzeyi, karaciğer ve böbrek fonksiyon testleri, gelişen komplikasyonlar, yoğun bakımda ve hastanede kalış süreleri ve mortalite oranları karşılaştırıldı.

BULGULAR: Çalışmaya 408'i Grup E, I40'ı Grup I olmak üzere toplam 548 hasta dahil edildi. Gruplar arası karşılaştırmalar sonucunda sedasyon gereksinimi, analjezi gereksinimi, mekanik ventilasyon süresi, ekstübasyon sonrası yüz maskesi oksijen gereksinimi, noninvaziv mekanik Grup E'de ventilasyon ihtiyacı, yeniden entübasyon gereksinimi ve kan şekeri düzeyi Grup l'e göre daha düşük bulundu. Ayrıca yoğun bakımda geçirilen süreler ve hastanede kalış süreleri Grup E'de Grup l'e göre daha düşük bulundu. Hastane mortalitesi açısından iki grup arasında fark bulunmadı.

TARTIŞMA: Torasik epidural analjezi, açık kalp cerrahisi geçiren yaşı hastalarda oluşturduğu analjezi ve sedasyon ile daha iyi solunumsal durum ve kan şekeri regülasyonu sağlayarak yoğunbakım ve hastanede kalış süresini kısaltmıştır.

Anahtar sözcükler: Ameliyat sonrası; kalp cerrahisi; torasik epidural analjezi; yaşlılık.

Ulus Travma Acil Cerrahi Derg 2022;28(3):382-389 doi: 10.14744/tjtes.2022.57995 